Gut, 1972, 13, 385-386

\title{
5-Hydroxyindole-secreting rectal carcinoid tumour
}

\author{
IAIN M. MURRAY-LYON, M. SANDLER, H. D. CHEETHAM, J. A. E. WATtS, \\ AND ROGER WILLIAMS
}

From the Liver Unit, King's College Hospital, London, Queen Charlotte's Maternity Hospital, London, and Dartford Hospital Group

SUMMARY A patient with a 5-hydroxyindole-secreting rectal carcinoid tumour is described, the second on record. There was no clinical evidence of carcinoid syndrome. Prostaglandin-like substances were isolated from hepatic metastases.

According to their widely accepted embryonic classification of carcinoid tumours (Williams and Sandler, 1963), growths arising in the rectum do not elaborate 5-hydroxyindoles. In one such patient in whom an equivocal rise in urinary 5-hydroxyindoleacetic acid (5-HIAA) output had been found the methodology was imprecise (Ahlgren and Wiklander, 1962). However, since then a single case report has appeared (Gross, 1968) and in this paper we describe a second patient with a 5-hydroxyindole-secreting rectal carcinoid tumour.

\section{Case Report}

This 42-year-old nursing sister presented in January 1964 with a three-month history of rectal bleeding. A pedunculated tumour was palpable on rectal examination and subsequently abdomino-perineal resection was performed. The mass $(3 \mathrm{~cm}$ diameter) arose $5 \mathrm{~cm}$ above the anal margin. All coats of the rectal wall were infiltrated and multiple small hepatic deposits were noted at operation. The microscopic appearances were those of an atypical carcinoid tumour with a ribbon-like pattern and a positive diazo-reaction.

Evidence that this tumour was biochemically active was first obtained in July 1968 when whole blood 5-hydroxytryptamine (5-HT) concentration (1.5 $\mu \mathrm{g} / \mathrm{ml}$; normal $<0.280 \mu \mathrm{g} / \mathrm{ml}$-Contractor, 1964) and 24-hour urinary excretion of 5-HIAA (155 $\mathrm{mg} / 24$ hours; normal $<8 \mathrm{mg} / 24$ hours-Udenfriend, Titus, and Weissbach, 1955) were found to be greatly increased. Urine indole chromatography (Jepson, 1955) revealed traces of 5-hydroxytryptophan (approximately $1.5 \mathrm{mg} / 24$ hours). Right heart catheterization (Dr J. M. Harrington) was normal and blood 5-HT concentrations in samples taken Received for publication 29 February 1972. from the superior vena cava, hepatic vein, and femoral artery were all comparably elevated (1.05$1.2 \mu \mathrm{g} / \mathrm{ml}$ ). Prostaglandins were not detected either in these samples or in peripheral venous blood (Miss E. Willman).

The patient remained well for four years and at no time showed symptoms of the carcinoid syndrome but by May 1969 the liver was massively enlarged and causing her considerable upper abdominal pain. In an attempt to reduce this, perfusion of the liver was carried out through a catheter inserted percutaneously. A total dose of 8.1g 5-fluorouracil was given over 14 days, this being limited because the hepatic artery arose from the superior mesenteric artery and the small bowel was being perfused simultaneously. Liver size decreased, urinary 5-HIAA output fell from a mean of $200 \mathrm{mg}$ to $120 \mathrm{mg} / 24$ hours, and whole blood 5-HT fell to almost normal levels $(0.36 \mu \mathrm{g} / \mathrm{ml})$. The original aim was to follow this by hepatic artery ligation but this proved technically impossible and a few weeks later she was given a course of radiotherapy to the liver in an applied dose of 3000 rads over a field $22 \times 22 \mathrm{~cm}$ during a fourweek period. Thereafter liver size decreased further and abdominal pain was much relieved. 5-HIAA excretion fell to $76 \mathrm{mg} / 24$ hours.

She was discharged home but died later from a massive haematemesis. At necropsy on 6 August 1969 a large penetrating duodenal ulcer was found which had also perforated into a cavity in the liver. The liver weighed $7000 \mathrm{~g}$ and was largely replaced by yellow deposits, many of which were necrotic and cystic. The microscopic appearances of the tumour were similar to those of the rectal primary. Prostaglandin-like substances were present in the hepatic metastases (Professor E. W. Horton). On the basis of chromatography and biological assay, it is likely that prostaglandins of both $\mathrm{E}$ and $\mathrm{F}$ type were represen- 
ted; mass spectrometric confirmation of their identity has not yet been obtained.

\section{Discussion}

Although the diazo and argentaffin reactions of rectal carcinoid tumours are usually negative, Gibbs (1963) drew attention to a minority group with a positive argentaffin reaction. This is indicative of a high local concentration of 5-HT (Benditt and Wong, 1957) which is presumably due to synthesis within the tumour cells. Thus the classification of these tumours according to their embryonic origin is to some extent an oversimplication and this point is emphasized by the excretion of traces of 5-hydroxytryptophan in the present patient, a finding more commonly associated with foregut tumours. The absence of flush was an indication that kinins were not liberated into the circulation in high concentration (Oates, Melmon, Sjoerdsma, Gillespie, and Mason, 1964) and it is of interest that prostaglandins, which are occasionally elaborated in excess by amine-peptide-secreting tumours (Sandler, Karim, and Williams, 1968), were found in significant concentrations in tumour tissue but not in blood from this patient.

With regard to treatment, the initial course of 5-fluorouracil undoubtedly had an effect on liver size as well as lowering blood 5-HT levels and urinary 5-HIAA excretion. This was given to diminish the risk, when the hepatic artery was later ligated, of precipitating a 'carcinoid crisis' due to sudden massive release of 5-HT from the tumour (Murray-
Lyon, Dawson, Parsons, Rake, Blendis, Laws, and Williams, 1970). Carcinoid tumours may sometimes respond to radiotherapy (Holsti, 1967) and in our patient this resulted in further reduction in liver size, fall in 5-HIAA output, and relief of symptoms, but it is possible that it contributed to the development of the duodenal ulcer responsible for her death.

\section{References}

Ahlgren, M., and Wiklander, O. (1962). Urinary 5-hydroxyindoleacetic acid and treatment of carcinoma of the rectum. Report of one case. Acta chir. scand., 124, 461-466.

Benditt, E. P., and Wong, R. (1957). 5-Hydroxytryptamine in enterochromaffin cells and its release by reserpine. Proc. Inst. Med. (Chic.), 21, 279-280.

Contractor, S. F. (1964). The estimation of 5-hydroxytryptamine in human blood. Biochem. Pharmacol., 13, 1351-1357.

Gibbs, N. M. (1963). The histogenesis of carcinoid tumours of the rectum. J. clin. Path., 16, 206-214.

Gross, M. (1968). Tumeurs carcinoides du rectum. Helv. chir. Acta, 35, 239-248.

Holsti, L. R. (1967). Radiotherapeutic aspects of intestinal carcinoid tumours. Radiol. clin. (Basel)., 36, 165-177.

Jepson, J. B. (1955). Paper chromatography of urinary indoles. Lancet, 2, 1009-1011.

Murray-Lyon, I. M., Dawson, J. L., Parsons, V. A., Rake, M. O., Blendis, L. M., Laws, J. W., and Williams, R. (1970). Treatment of secondary hepatic tumours by ligation of hepatic artery and infusion of cytotoxic drugs. Lancet, 2, 172-175.

Oates, J. A., Melmon, K., Sjoerdsma, A., Gillespie, L., and Mason, D. T. (1964). Release of a kinin peptide in the carcinoid syndrome. Lancet, 1, 514-517.

Sandler, M., Karim, S. M. M., and Williams, E. D. (1969). Prostaglandins in amine-peptide-secreting tumours. Lancet, 2, 10531055.

Udenfriend, S., Titus, E., and Weissbach, H. (1955). The identification of 5-hydroxy-3-indoleacetic acid in normal urine and a method for its assay. J. biol. Chem., 216, 499-505.

Williams, E. D., and Sandler, M. (1963). The classification of carcinoid tumours. Lancet, 1, 238-239. 